\title{
SIMPLE METHOD TO PRODUCE NANOPOROUS CARBON FOR VARIOUS APPLICATIONS BY PYROLYSIS OF SPECIALLY SYNTHESIZED PHENOLIC RESIN
}

\author{
Imam Prasetyo ${ }^{1, *}$, Rochmadi, Teguh Ariyanto, and Rakhmat Yunanto \\ Chemical Engineering Department, Universitas Gadjah Mada, \\ Jl. Grafika, No. 2, Yogyakarta 55281, Indonesia
}

Received January 18, 2013; Accepted June 22, 2013

\begin{abstract}
Nanoporous carbon materials, a unique and useful material, have been widely used in many technologies such as separation processes, catalysis, energy storage, gas storage, energy conversion, etc. due to its high specific surface area and tunable porosity. In this research, nanoporous carbons were prepared using simple and innovative approach based on structural array of phenolic resin polymer without activation during carbonization process. The effect of phenolic reactant type and composition on pore structure and carbon surface morphologies was studied. Nanoporous carbon derived from resorcinol formaldehyde (RF) and from resorcinol phenol formaldehyde (RPF) polymers was suitable for electrode material supercapacitor and $\mathrm{CO}_{2}$ capture medium. RF-derived and RPF-derived carbons provide electrode material supercapacitor with specific capacitance up to $246 \mathrm{~F} / \mathrm{g}$, whereas carbonized RPF exhibited $\mathrm{CO}_{2}$ uptake of $10.63 \mathrm{mmol} / \mathrm{g}$ (at $3.5 \mathrm{MPa} 298 \mathrm{~K}$ ). Nanoporous carbon derived from resorcinol para-tertbutyl phenol formaldehyde (RTBPF) polymer exhibited attractive characteristics as methane storage media with methane uptake capacity as high as $8.98 \mathrm{mmol} / \mathrm{g}$ (at $3.5 \mathrm{MPa} 298 \mathrm{~K}$ ).
\end{abstract}

Keywords: porous carbon; phenolic formaldehyde polymer; supercapacitor; gas storage

\section{ABSTRAK}

Material karbon nanopori, sebuah material yang unik dan berguna, telah digunakan secara luas di berbagai bidang teknologi seperti proses pemisahan, katalis, penyimpan energi, penyimpan gas, dan konversi energi dikarenakan luas permukaan spesifik yang tinggi dan porositas yang mudah diatur. Pada penelitian ini, karbon berpori dibuat dengan cara yang mudah dan inovatif berdasar pada struktur polimer dari fenolik resin tanpa adanya proses aktivasi pada proses karbonisasi. Pengaruh tipe reaktan fenolik (fenol, resorsinol, para-tersierbutilfenol) dan komposisinya terhadap struktur pori dan morphologi permukaan karbon telah dipelajari pada penelitian ini. Karbon berpori yang diperoleh dari karbonisasi polimer resorsinol formaldehid (RF) dan resorsinol fenol formaldehid (RPF) sesuai untuk digunakan sebagai material elektroda superkapasitor dan media penjerap $\mathrm{CO}_{2}$. Karbon $\mathrm{RF}$ dan karbon RPF memiliki nilai spesifik kapasitansi superkapasitor mencapai $246 \mathrm{~F} / \mathrm{g}$ sedangkan karbon RPF menunjukan nilai penjerapan $\mathrm{CO}_{2}$ sebesar 10,63 mmol/g (3,5 MPa, $\left.298 \mathrm{~K}\right)$. Karbon berpori yang diperoleh dari karbonisasi polimer resorsinol para-tert-butilfenol formaldehid (RTBPF) menunjukkan karakteristik yang sangat sesuai sebagai media penyimpan gas metan dengan kapasitas penyimpanan sebesar 8,98 mmol/g (3,5 MPa, $298 \mathrm{~K})$.

Kata Kunci: karbon berpori; polimer fenolik formaldehid; superkapasitor; penyimpan gas

\section{INTRODUCTION}

Nanoporous carbons have been widely used in many technologies such as separation processes, catalysis, energy storage, gas storage, energy conversion, etc. [1-3]. Preparations of nanoporous carbon with different methods and precursors have been performed by various research groups to search for material which is suitable for particular purpose [4-6]. Nanoporous carbon can be made by controlled pyrolysis of various natural carbonaceous matters such as coal, nut shell, cornstalks, wood, bamboo [8-10] or synthetic polymer such as phenol formaldehyde, polyaniline, and melamine formaldehyde [11-13]. Compared to the natural precursor, the structure and purity of synthetic polymer could be controlled easily.

It has been generally known that the pore structure of the porous carbon is affected by the nature of the precursor, pyrolysis method, and post-treatment conditions (activation processes) [14-16]. Phenolic formaldehyde polymers have been increasingly used as precursor for porous carbon preparation due to its specific three dimensional structures of the polymer framework and thermosetting properties [17], however

* Corresponding author. Tel/Fax : +62-274-902171/6492170

Email address : imampras@chemeng.ugm.ac.id

Imam Prasetyo et al. 
there has not been a systematic effort to relate the structural properties and the morphologies of the carbonized polymers to the type and the composition of the reactant used in the polymerization processes. In our present study, nanoporous carbons were prepared by pyrolysis of specially synthesized phenolic formaldehyde polymer without any additional activation processes. In this approach, various phenolic compounds and composition of reactant were employed to obtain nanoporous carbon with specific properties which is suitable for application of electrode material supercapacitor, methane storage medium, and $\mathrm{CO}_{2}$ capture medium.

\section{EXPERIMENTAL SECTION}

\section{Materials}

The materials used in polymer preparation were phenolic compounds (phenol $(P)$, resorcinol $(R)$, and para-tert-butyl-phenol (TBP)), and formaldehyde (F). Hydrochloric acid was used as catalyst in the polymerization reaction. Nitrogen gas with purity of $99.95 \%$ was supplied as a carrier gas during carbonization processes whereas ultra-high purity of compressed nitrogen (99.9995\%) and liquid nitrogen were employed as the adsorbate in the measurement of BET surface area and as the coolant, respectively. The materials used in the preparation of supercapacitor electrodes were the resulted carbon as active material, carbon black as conductor, and polyvinyl alcohol (PVA) as binder while $\mathrm{KOH} 30 \%$ is used as an electrolyte solution in the supercapacitor testing. Furthermore, $\mathrm{CH}_{4}$ and $\mathrm{CO}_{2}$ high purity gases are used in the porous carbon applications as methane storage medium and $\mathrm{CO}_{2}$ capture material.

\section{Instrumentation}

The instrumentations used in this research were JSM-6360LA (JEOL) analytical scanning electron microscope and NOVA 2000 gas sorption and porosity analyzer.

\section{Procedure}

\section{Precursors and nanoporous carbons preparation}

Polymeric precursors were prepared through polycondensation reaction of phenolic compound with formaldehyde, under acidic condition. Phenolic compounds used in this experiment were phenol $(P)$, resorcinol $(R)$, and para-tert-butyl-phenol (TBP). Four different polymeric precursors prepared in this experiment were: phenol formaldehyde (PF), resorcinol formaldehyde (RF), resorcinol phenol formaldehyde
(RPF), and resorcinol para-tert-butyl-phenol formaldehyde (RTBPF).

Carbonization of the polymeric precursor was carried out in a furnace under flowing nitrogen (100 $\mathrm{mL} / \mathrm{min}$ ) from room temperature up to $1023 \mathrm{~K}$ at a heating rate of $3 \mathrm{~K} / \mathrm{min}$ and kept at $1023 \mathrm{~K}$ for $2 \mathrm{~h}$. Then the furnace was allowed to cool down to room temperature under nitrogen flow and the obtained carbon sample was washed with distilled water. Finally, the sample was dried at $383 \mathrm{~K}$.

\section{Structure and physical properties of nanoporous carbon}

The surface morphologies of porous carbon materials were observed by JSM-6360LA (JEOL) analytical scanning electron microscope, and pore structure was measured with a NOVA 2000.

\section{Porous carbon application}

The specific capacitance of supercapacitor was measured by two-electrode system in a galvanostatic mode using $30 \% \mathrm{KOH}$ as an electrolyte and a piece of polypropylene membrane as a separator. The positive and negative carbon electrodes were prepared by addition $80 \mathrm{wt} \%$ of porous carbon powders and $10 \mathrm{wt} \%$ of CB in $10 \mathrm{wt} \%$ of PVA dispersed in ethanol $70 \%$ to yield a homogeneous paste. The paste obtained was then rolled into $1 \mathrm{~cm}^{2}$ size Cu collector with a thickness of $\pm 0.20 \mathrm{~mm}$. The weight of the porous carbon powder (active material) was around 5-10 mg. The $\mathrm{CO}_{2}$ and $\mathrm{CH}_{4}$ adsorption capacity test of the porous carbons were carried out in an ultrahigh vacuum rig using volumetric method at desired temperatures and in the pressure range of $0-4 \mathrm{MPa}$. The adsorption measurement apparatus was constructed by Swagelok $V_{C}{ }^{\circledR}$ fittings.

\section{RESULT AND DISCUSSION}

In this research, nanoporous carbons for application of electrode material supercapacitor, methane storage medium, and $\mathrm{CO}_{2}$ capture medium were prepared by using simple and innovative approach based on structural array of phenolic resin polymer without activation during carbonization process. The effect of reactant type and composition used in the polymerization processes on properties and the morphologies of the carbonized polymers was studied.

\section{Morphology of the Carbons}

The representative structures of PF, RF, RPF, and RTBPF polymers are shown in Fig. 1a, 1b, 1c, and 1c. Phenol, resorcinol, and para-tert-butyl phenol will 


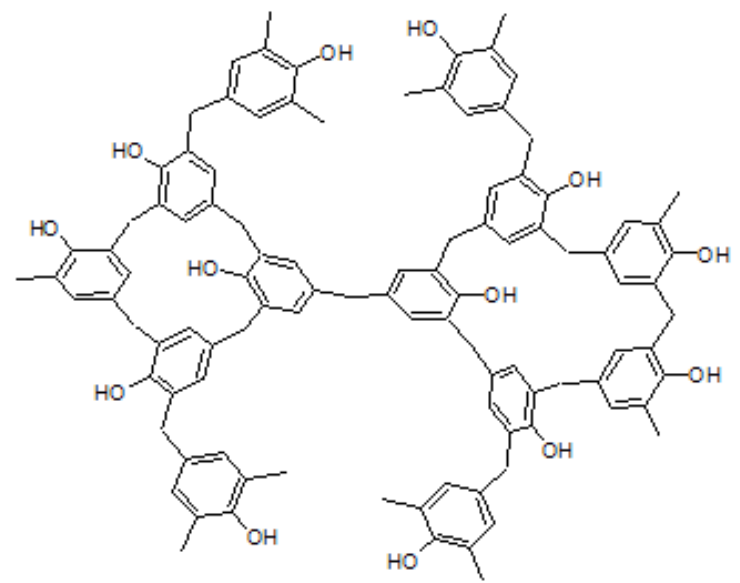

Fig 1a. Representative structure of PF polymer

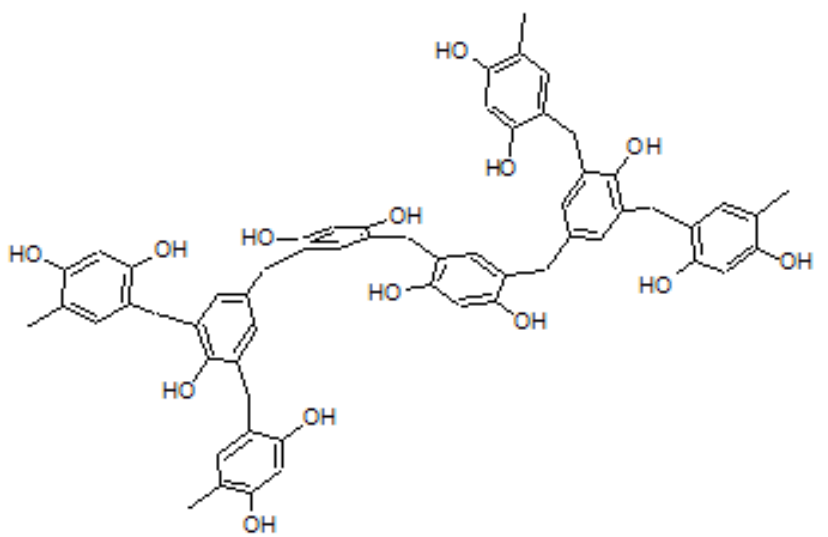

Fig 1c. Representative structure of RPF polymer

react with formaldehyde in a similar mechanism, but the presence of $-\mathrm{OH}$ functional group in resorcinol and butyl functional group in para-tert-butyl phenol will direct the formation of polymer structures differently. Formaldehyde reacts with phenol at random ortho and para directions (position 2, 4 and 6) to produce irregular network structure [17] while due to steric effect caused by the presence of $-\mathrm{OH}$ functional group in metaposition of the phenol ring, formaldehyde reacts with resorcinol more in positions 4 and 6 to produce more a linear network structure. In the case of para-tert-butyl phenol, formaldehyde reacts with its phenolic compound only at the two ortho-positions to produce a linear network structure. Hence the order of linearity of the network structure is RTBPF, RF, RPF, and PF resin. The surface morphologies of the carbons obtained from pyrolysis of those polymers (PF, RF, RPF, and RTBPF) were observed using SEM and presented in Fig. $2 a, 2 b$, $2 c$, and $2 d$, respectively. It appears that difference carbon precursor produces different surface morphology. The more linear structure of polymeric resin, the more cavities is observed. Thus, it is obvious that the different in carbon surface morphology could be attributed to the nature of the polymeric precursor.

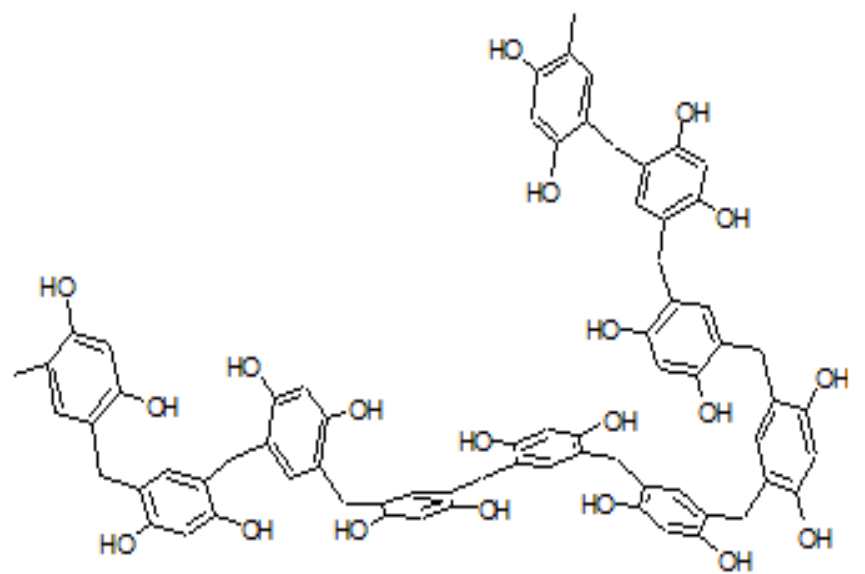

Fig 1b. Representative structure of RF polymer<smiles>Cc1cc(Cc2cc(C(C)C)cc(Cc3cc(Cc4cc(O)c(Cc5cc(Cc6cc(C(C)C)cc(O)c6O)c(O)cc5O)cc4O)c(O)cc3O)c2O)c(O)cc1O</smiles>

Fig 1d. Representative structure of RTBPF polymer

\section{Pore Structure of the Carbons}

The micropore structure of the carbon was analyzed by $\mathrm{N}_{2}$ adsorption/desorption BET measurement. The $\mathrm{N}_{2}$ adsorption isotherm of the carbons is presented in Fig. 3. Ajax ${ }^{\circledR}$ commercial activated carbon is presented for comparison with the prepared carbons. According to the IUPAC classification, the entire isotherm of the samples is type I characteristics which means that they have dominantly micropore structure with pore diameter less than $2 \mathrm{~nm}$. Besides, Fig. 3 shows that the difference type of precursor will affect the adsorption isotherm of the product. It is shown that increasing adsorption isotherm at $\mathrm{P} / \mathrm{P}_{\mathrm{o}} \sim 1$ which is related with the presence of mesopore structure (pore diameter between 2-50 $\mathrm{nm}$ ) is occurred in the resulted carbon when resorcinol is employed as a reactant.

The results of calculations based on the $N_{2}$ adsorption and desorption isotherm were summarized in Table 1. It is shown that all of the samples have a high surface area, $S$. The difference in surface area enhancement between RTBPF carbon $\left(2248 \mathrm{~m}^{2} / \mathrm{g}\right)$ and $\operatorname{RPF}\left(2174 \mathrm{~m}^{2} / \mathrm{g}\right)$ carbon suggest that the type of the 


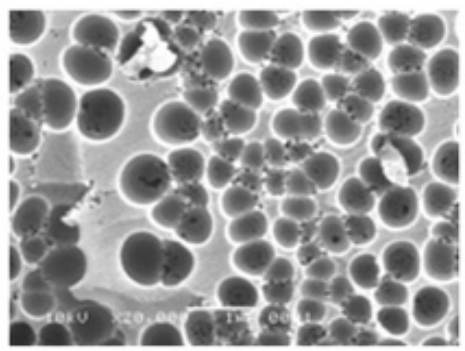

Fig 2a. SEM image of PF carbon

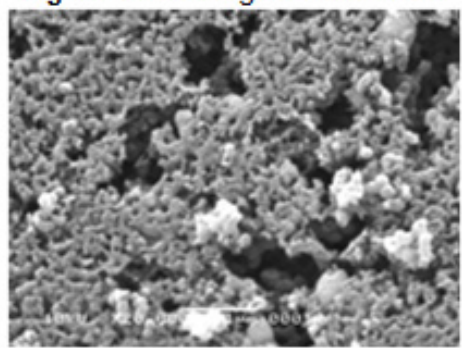

Fig 2c. SEM image of RPF carbon Fig 2d. SEM image of RTBPF carbon

Table 1. Porous textural parameters of carbon materials

\begin{tabular}{cccccccc}
\hline Sample & $S, \mathrm{~m}^{2} / \mathrm{g}$ & $S_{\text {mic }}, \mathrm{m}^{2} / \mathrm{g}$ & $\% S_{\text {mic }}$ & $V, \mathrm{~cm}^{3} / \mathrm{g}$ & $V_{\text {mic }}, \mathrm{cm}^{3} / \mathrm{g}$ & $\% V_{\text {mic }}$ & $D_{\text {avg }}, \mathrm{nm}$ \\
\hline PF & 782 & 695 & 88.875 & 0.412 & 0.306 & 74.24 & 2.11 \\
RF & 1457 & 1177 & 80.782 & 0.926 & 0.503 & 54.32 & 2.54 \\
RPF & 2174 & 1725 & 79.347 & 1.262 & 0.662 & 52.46 & 2.32 \\
RTBPF & 2248 & 1862 & 82.829 & 1.199 & 0.723 & 60.32 & 2.13 \\
Ajax Com. AC & 1171 & 947 & 80.870 & 0.662 & 0.375 & 56.65 & 2.26 \\
\hline
\end{tabular}

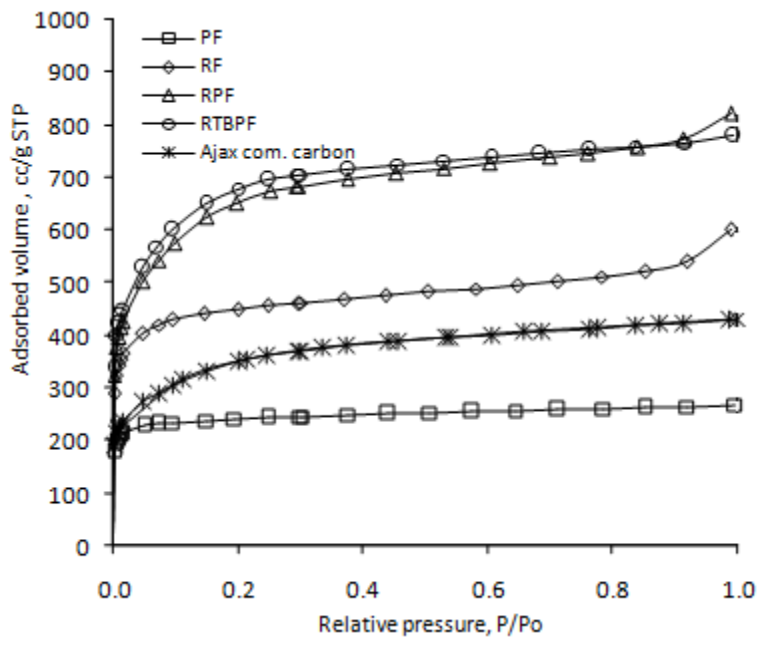

Fig 3. $N_{2}$ adsorption of porous carbon derived from various polymers

substitute phenol added determine the micropore structure of the carbon. These values are comparable with or even higher than other researches using synthetic polymer as precursor using activation processes (chemical or physical activations) [1,13-14]. In line with $\mathrm{N}_{2}$-adsorption isotherm, it seems that the carbon produced from polymeric precursor in the presence of resorcinol has lower both of the percentage of micropore surface area, $S_{\text {mic }}$, and the percentage of

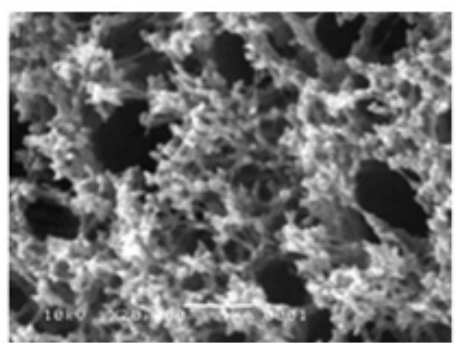

Fig 2b. SEM image of RF carbon

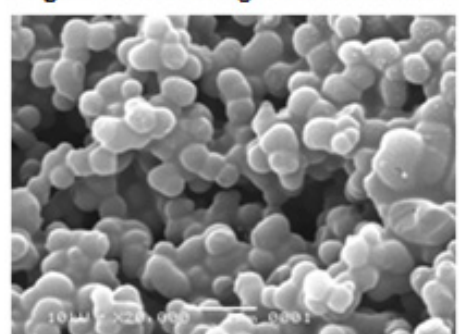

micropore volume, $V_{\text {mic }}$, than carbon produced from $\mathrm{PF}$ polymer. In other words, the irregular structure of PF polymer exhibited higher microporosity than the regular structure of polymer.

\section{Applications of the Carbons}

\section{Nanoporous carbon as an electrode material supercapacitor}

Nanoporous carbon for electrode material supercapacitor was prepared from resorcinol formaldehyde (RF) and from resorcinol phenol formaldehyde (RPF). Phenol formaldehyde (PF) polymer was also prepared under the same condition for comparison with the investigated precursors. The choice of those of three carbons is appropriate since they represent a wide pore structure such as the surface area and the pore volume. Therefore, they are suitable for studying of the effect of the pore structure on the supercapacitor application. The specific capacitance of the porous carbon material electrode was be measured by simple test with constant current charge-discharge method. Capacitance $(C)$ value is defined as the ratio of charge $(q)$ to applied voltage $(E)$ or it is presented by the following equation:

$C=\frac{d q}{d E}$ 
Table 2. Specific capacitance obtained from constant current-discharge method

\begin{tabular}{ccccc}
\hline Sample & $S S A, \mathrm{~m}^{2} / \mathrm{g}$ & $V, \mathrm{~cm}^{3} / \mathrm{g}$ & $V_{\text {mic }}, \mathrm{cm}^{3} / \mathrm{g}$ & $C_{g}, \mathrm{~F} / \mathrm{g}$ \\
\hline PF & 782 & 0.412 & 0.306 & 56 \\
RPF & 2174 & 1.262 & 0.662 & 246 \\
RF & 1457 & 0.926 & 0.503 & 229 \\
\hline
\end{tabular}

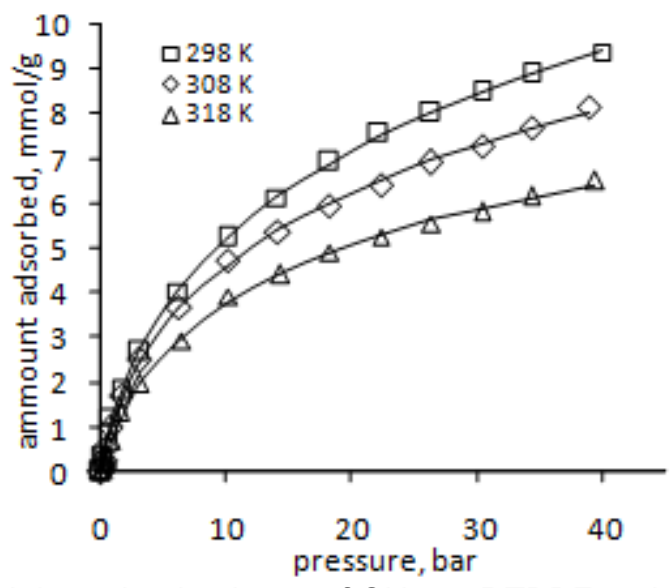

Fig 4. Adsorption isotherm of $\mathrm{CH}_{4}$ on $\mathrm{RTBPF}$ carbon

Table 3. Toth parameters and heat of adsorption of $\mathrm{CH}_{4}$ on RTBPF carbon

\begin{tabular}{lrrr}
\hline & \multicolumn{3}{c}{ Temperature } \\
\cline { 2 - 4 } & $298 \mathrm{~K}$ & $308 \mathrm{~K}$ & $318 \mathrm{~K}$ \\
\hline$C_{\mu}[\mathrm{mmol} / \mathrm{g}]$ & 31.63 & 22.13 & 11.42 \\
$b[1 / \mathrm{bar}]$ & 0.113 & 0.126 & 0.113 \\
$t$ & 0.373 & 0.412 & 0.595 \\
$\Delta H[\mathrm{~kJ} / \mathrm{mol}]$ & 25 & & \\
\hline
\end{tabular}

The specific capacitance of the porous carbon material as calculated from those equations is listed in Table 2. The data shows that nanoporous carbon derived from pyrolysis of RF and RPF polymers provide attractive electrode material supercapacitor [1] with specific capacitance of 229 and $246 \mathrm{~F} / \mathrm{g}$, respectively. The specific capacitance increases with increasing the surface area of porous carbon as active surface of electrode. Furthermore RF and RPF carbons has high portion of mesopore, $\left(V-V_{\text {mic }}\right) / V$ which lead ions transport in the pore quickly and increase the efficiency of surface area.

\section{Nanoporous carbon as $\mathrm{CH}_{4}$ storage medium}

Nanoporous carbon for methane storage medium was derived from pyrolysis of RTBPF polymer. The RTBPF carbon has the high surface area and high microporosity which its characterizations are suitable for methane adsorption [18]. It is well known that the higher surface area leads to the higher adsorption capacity. The equilibrium adsorption of methane on the porous carbon was measured at three different temperatures (298, 308, and $318 \mathrm{~K})$. The adsorption isotherms in the pressure range of 0-40 bar are shown in Fig. 4.

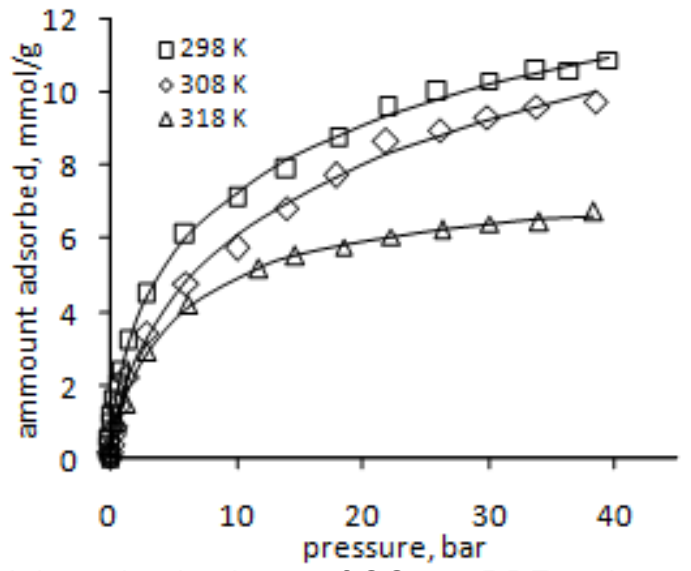

Fig 5. Adsorption isotherm of $\mathrm{CO}_{2}$ on RPF carbon

These isotherm data were well fitted by the Toth equation:

$$
C_{\mu}=C_{\mu s} \frac{b P}{\left[1+(b P)^{t}\right]^{1 / t}}
$$

The parameter of $C_{\mu}$ is the adsorption capacity while the parameter of $b$ and $t$ are the adsorption affinity and adsorption system heterogeneity, respectively. The optimal parameter $C_{\mu}, b$, and $t$ for the methane are presented in Table 3 . It is clear that the higher the temperature the lower the maximum adsorption capacity. It seems that the system heterogeneity increases with increasing the adsorption temperature since value of $t$ is deviated further away from unity with decreasing temperature. The heat of adsorption at zero loading, $\Delta H$ as calculated from Clapeyron equation is also included in the table.

It can be seen in Fig. 4 that nanoporous carbon derived from resorcinol para-tert-butyl phenol formaldehyde (RTBPF) polymer exhibited attractive characteristics as methane storage media with methane uptake capacity as high as $8.98 \mathrm{mmol} / \mathrm{g}$ (at 3.5 MPa and $298 \mathrm{~K}$ ).

\section{Nanoporous carbon as $\mathrm{CO}_{2}$ capture material}

Nanoporous carbon for $\mathrm{CO}_{2}$ capture material was derived from pyrolysis of RPF polymer. The choice of RPF carbon is appropriate for testing the $\mathrm{CO}_{2}$ capture since it has high surface area as high as RTBPF carbon with the lowest microporosity [18]. The uptake capacity of the carbon toward $\mathrm{CO}_{2}$ gas was measured at three different temperatures $(298,308$, and $318 \mathrm{~K})$. 
Table 4. Toth parameters and heat of adsorption of $\mathrm{CO}_{2}$ on RPF carbon

\begin{tabular}{lrrr}
\hline & \multicolumn{3}{c}{ temperature } \\
\cline { 2 - 4 } & $298 \mathrm{~K}$ & $308 \mathrm{~K}$ & $318 \mathrm{~K}$ \\
\hline$C_{\mu}[\mathrm{mmol} / \mathrm{g}]$ & 25.863 & 24.08 & 7.88 \\
$b[1 / \mathrm{bar}]$ & 0.604 & 0.184 & 0.229 \\
$t$ & 0.341 & 0.417 & 0.854 \\
$\Delta H[\mathrm{~kJ} / \mathrm{mol}]$ & 27 & & \\
\hline
\end{tabular}

The adsorption isotherms in the pressure range of $0-40$ bar are shown in Fig. 5. The Toth parameters of $\mathrm{CO}_{2}$ on RPF-derived carbon are listed in Table 4. According to the parameters, the adsorption capacity, $C_{\mu s}$, decreases with increasing adsorption temperature while the system heterogeneity, $t$, increases with increasing the adsorption temperature. Fig. 5 shows that carbonized RPF exhibited competitive $\mathrm{CO}_{2}$ uptake of $10.63 \mathrm{mmol} / \mathrm{g}$ (at $3.5 \mathrm{MPa}$ and $298 \mathrm{~K}$ ).

\section{CONCLUSION}

Preparing nanoporous carbon for various applications by pyrolysis of specially synthesized phenolic resin has been examined. In this method, nanoporous carbons were prepared using simple and innovative approach based on structural array of phenolic resin polymer without activation during carbonization process. In the preparation of the phenolic formaldehyde polymer, various phenolic compounds, such as: phenol, resorcinol, and para-tert-butyl phenol, were used in order to obtain polymer material which is suitable for preparation of various nanoporous carbons. This new, simple and innovative approach yielded porous carbon which is suitable for application of electrode material supercapacitor, methane storage medium, and $\mathrm{CO}_{2}$ capture medium.

\section{REFERENCES}

1. Zhu, Y., Hu, H., Li, W., and Zhang, X., 2007, Carbon, 45, 1, 160-165.

2. Meisner, G.P., and Hu, Q., 2009, Nanotechnology, 20, 204023.

3. Viswanathan, B., Indra Neel, P., and Varadarajan, T.K., 2009, Methods of Activation and Specific
Applications of Carbon Materials, National Centre for Catalysis Research, India.

4. Zhang, T., Walawender, W.P., and Fan, L.T., 2005, Sep. Purif. Technol., 44, 247-249.

5. Prasetyo, I., Rochmadi, Yunanto, R., Ariyanto, T., and Wiratni, 2010, Proceedings of $17^{\text {th }}$ Regional Symposium on Chemical Engineering (RSCE), Thailand.

6. Liu, C.L., Dong, W., Cao, G., Song, J., Liu, L., and Yang, Y., 2008, J. Electrochem. Soc., 155, 1, F1F7.

7. Maciá-Agulló, J.A., Moore B.C., Cazorla-Amoróz, D., and Linares-Solano, A., 2004, Carbon, 42, 7, 1367-1370.

8. Tangjuank, S., Insuk, N., Tontrakoon, J., and Udeye, V., 2009, World Academy of Science, Engineering and Technology, 52, 110-116.

9. Zhang, F., Hua, M., Chen, J., Li, G-D, Zhang, Y., and Chen, J-S., 2008, Bioresour. Technol., 99, 11, 4803-4808.

10. Wei, S., Li, Z., and Yaping, Z., 2006, Chin. J. Chem. Eng., 14, 2, 266-269.

11. Kobayashi, N., and Kijima, M., 2007, J. Mater. Chem., 17, 4289-4296.

12. Ariyanto, T., Prasetyo, I., and Rochmadi, 2012, Reaktor, 14, 25-32.

13. Hulicova, D., Yamashita, J., Soneda, Y., Hatori, H., and Kodama, M., 2004, Chem. Mater., 17, 5, 1241-1247.

14. Lenghaus, K., Qiao, G.G., Solomon, D. H., Gomez, C., Rodriguez-Reinoso, F., and SepulvedaEscribano, A., 2002, Carbon, 40, 5, 743-749.

15. Cai, Q., Huang, Z-H., Kang F., and Yang J-B., 2004, Carbon, 42, 4, 775-783.

16. Solar, C., Sardella, F., Deiana, C., Logo, R.M., Vallone, A., and Sapag, K., 2008, Mater. Res., 11, 4, 409-414.

17. Kumar, A., and Gupta, R.K., 1998, Fundamentals of Polymers, McGraw-Hill Book Co., Singapore, 96-98.

18. Himeno, S., Komatsu, T., and Fujita, S., 2005, J. Chem. Eng. Data, 50, 2, 369-376. 